Journal of the Scholarship of Teaching and Learning, Vol. 21, No. 4, December 2021, pp. 124-133. doi: 10.14434/josotl.v21i4.32709

\title{
Teaching Issues of Equity and Oppression in a Business Ethics Course
}

\author{
Shawna Eikenberry and April Sellers \\ Indiana University Bloomington
}

\begin{abstract}
In this essay, we reflect on our experience teaching divisive issues to undergraduates in a required business ethics class. We want to share lessons learned, and what worked and what did not, in hopes that it will help other instructors who are tackling these topics. In particular, we share a list of "guiding principles" we developed that we find helpful in teaching a class that involves polarizing topics.
\end{abstract}

Keywords: teaching diversity, business ethics pedagogy.

\section{The Challenge}

We teach a required ethics course at the Indiana University Kelley School of Business. The class has always included some topics that can be divisive (implicit bias, for example). And as lawyers, we have long known and taught about how the law has historically favored or disfavored certain groups. But beginning last year, our department identified the course as one that would meet the University's diversity initiative. This meant that among other learning goals, students taking the course should be able to:

Identify, analyze, and evaluate the ways in which individuals and groups in the US have unequal experiences, access to opportunity, or life outcomes based on the intersections of race, gender, social class, citizenship, (dis)ability, indigeneity, sexual orientation, religion and creed, or other dimensions of difference. (Bloomington Faculty Council, n.d.).

Those new learning goals meant that we would be navigating some tough conversations in the classroom.

Many scholars have noted best practices for teaching controversial topics. We have tried to rely on those methods, which include introducing topics incrementally (Pace, 2003) ${ }^{1}$; using group work (Davidson \& Major, 2014); letting students guide the discussion rather than relying on lecture (Pace, 2003); keeping in mind that student views often come from deep-seated religious and/or moral beliefs; starting with less controversial, "less complex or emotionally-charged" ideas before diving into those that are more polarizing (Indiana University Center for Innovative Teaching and Learning, n.d.); developing community in the classroom and helping students get to know each other (Harvard University Derek Bok Center for Teaching and Learning, n.d.); and allowing students to write reflective pieces before discussing hot topics (University of Michigan Center for Research on Learning \& Teaching, n.d.). All of these methods have been enormously helpful; in this essay, we say more about how we used these and other practices in our classes.

The new emphasis on equity issues in our business ethics classes coincided with the death of George Floyd, the COVID-19 pandemic, and increased awareness of violence against Asian

\footnotetext{
${ }^{1}$ Pace recommended an incremental approach to teaching controversial or upsetting subjects, such as starting with a series of small discussion points before opening up the class to a larger discussion of the topic.
} 
Americans. For all of these reasons, this course has become a concentrated place where polarizing topics are taught in a particularly polarized environment (see, e.g., Finkel et al., 2020; see also Dimock \& Gramlich, 2021, who explained that between 1994 and 2017, the gap between responses of Democrats and Republicans to a variety of questions about values tripled, reflecting a "steady, decades-long increase in polarization," and Gilberstadt et al., 2020, who noted that when it comes to matters of race and gender, the gap between Biden and Trump supporters in 2020 was much wider than between Trump and Clinton in 2016).

Think of an issue that most people consider to be polarizing, and there is a good chance it is covered in our course. These issues include but are not limited to affirmative action; the historical oppression of various peoples, often with the blessing of the law; the rights of people based on sexual orientation or gender identity; reparations; the role of business or government in addressing inequities; and whether any discrimination should be allowed on religious grounds.

Our students come from diverse backgrounds and geographic locations; some are the first in their families to attend college. They are disproportionately White and male. Many tell us they know little about the struggles and obstacles of women, people of color, or disabled people. One student described her learning before the class this way: "We learn about slavery, and Jim Crow, and then we learn that that's all in the past and everything is fine." In fact, surveys indicate there is no national consensus about whether it is a good idea to teach the history of racism. The Pew Research Center (2021) found that "among U.S. adults overall, 53\% say increased attention to that history [of slavery and racism] is a good thing for society, while 26\% say it is a bad thing and another $21 \%$ say it is neither good nor bad." While some students have no doubt had excellent civics classes in high school, data suggest that education is uneven at best across the United States. Hansen (2020), reporting on results from the 2018 National Assessment of Education Progress civics assessment, stated that "less than a quarter of students demonstrated solid academic performance and competency in civics and government." With such diverse backgrounds, it is not surprising that some students (certainly not all or even many) seem hostile to class goals; they feel defensive at the idea of learning about racial justice and assume the class is in furtherance of our own "feminist" or liberal agendas.

Reflecting on our experiences, we realize that some of our strategies were more effective than others. And since we still have much to learn, looking back can provide insight about how to approach these topics more productively in the future. Pedagogical experts support the notion of teaching divisive issues in the classroom. For instance, McAvoy and Hess (2013) noted that learning to talk about political differences is a "democracy-sustaining" approach to education, because learning to talk effectively about the issues of the day is the cornerstone of a healthy and well-functioning democracy," and that "researchers and practitioners have identified classrooms as one of the most promising sites for teaching the skills and values necessary for deliberative democratic life." (p. 17, 19)

\section{Class Goals}

Given how polarizing these topics can be, it is easy to find articles about how and why "diversity training" fails and/or backfires (e.g., Dobbin \& Kelev, 2016, Grobman, 2019). Moreover, research shows that people can become even more entrenched in their own viewpoints when confronted with conflicting arguments (e.g., Bail et al., 2018; but see Wood \& Porter, 2019, who found that "evidence of factual backfire is far more tenuous than prior research" but also that most studies that have found a backfire effect have been among college students). Thus, one goal was simply not to make things worse by further alienating students (see, e.g., Kernahan, 2019, on why students resist learning about topics such as race). On the flip side, some students are eager to explore these ideas, and another goal is to make those students feel comfortable in discussing their own experiences. And in the middle, we

Journal of the Scholarship of Teaching and Learning, Vol. 21, No. 4, December 2021. josotl.indiana.edu 
have students who simply have not thought much about many of these topics or who maybe are just beginning to think about them, particularly in light of the events of 2020 .

Given all of this, three goals stood out. First was to educate students with information about historic and current inequities. Business students tend to appreciate facts and data. Thus, giving them information they might not otherwise have not only helps students learn but also gives students the knowledge necessary to competently discuss these topics in the workplace. The second goal is to have students critically examine their beliefs about these topics using that learned information. Larry Churchill (2020) discussed the importance of "unpacking your moral backpack," and getting students to examine their beliefs about race, gender, sexuality, disability, class, and similar topics is part of this. The third goal is to help our students become better and more empathetic businesspeople and leaders. Given businesses' increasing emphasis on equity and related issues, it is in our students' best interest to be competent in this area.

Importantly, our goal is not to change students' minds or to have them believe what we believe. Rather, we hope to give them knowledge they might not have had before, to create in them a willingness to better understand others' perspectives, and to encourage them to evaluate their own beliefs about these important issues.

\section{Guiding Principles}

Whether by design or not, several big ideas emerged about what works and what does not.

\section{Facts and History}

Any debate about a controversial issue should start with finding common ground. In the midst of different opinions about issues such as race and gender, facts can provide a starting place, and it is particularly important to discuss historical practices and their continuing effects (see, e.g., Eberhardt, 2020 , p. 17, 19, who explained the importance of interpersonal connections in breaking stereotypes, as well as the important role of education: "How do certain people or entire social groups land in the positions they are in? Young people need to understand the history that created structural barriers to integration and equity"; see also Kernahan, 2019, who explained the importance of starting with American history when discussion the psychology of prejudice and racism). For example, here are some facts that we start with:

- Redlining existed, both as official policy and private practice. Many students are unaware of the history of redlining and how it affects wealth inequality even today. A good resource is Coates's (2014) article about reparations. Although the topic can be polarizing, the article is a history lesson on redlining and the role of business in perpetuating it. Similarly, the book The Color of Law by Richard Rothstein (2017) is a comprehensive history of the issue, ${ }^{2}$ with examples like this restrictive covenant from California in 1950:

The real property described above, or any portion thereof, shall never be occupied, used or resided on by any person not of the white or Caucasian race, except in the capacity of a servant or domestic employed thereon as such by a white Caucasian owner, tenant or occupant. (pp. 78-79)

\footnotetext{
${ }^{2}$ Mr. Coates's interview with Mr. Rothstein is available at https://www.youtube.com/watch? $\mathrm{v}=9 \mathrm{~Pb} 6 \mathrm{y} 9 \mathrm{rNKmo}$.

Journal of the Scholarship of Teaching and Learning, Vol. 21, No. 4, December 2021. josotl.indiana.edu
} 
And the National Association of Real Estate Board's code of ethics essentially codified discrimination, stating that "a Realtor should never be instrumental in introducing into a neighborhood ... any race or nationality, or any individuals whose presence will clearly be detrimental to property values." (Rothstein, 2017, p. 52).

- A racial wealth gap exists. Typical White families have eight times the wealth of Black families and five times the wealth of Hispanic families. (Bhutta et al., 2020) This statistic and related information about its possible causes help students evaluate how justice and fairness relate to continuing inequalities.

- Discrimination was legal until relatively recently, still exists today, and is difficult to prove. Multiple studies have shown the effects of discrimination (e.g., Quillian et al., 2017), and it is helpful for students to understand the extent to which blatant discrimination was perfectly legal until relatively recently. Congress passed the Americans with Disabilities Act, for example, in 1990. Moreover, victims still face a difficult burden of proof, and examples of this can be enlightening.

- The world is large and diverse. For college students surrounded by other students (and even for faculty), it is easy to have an unstated perception that others are like us. That, of course, is just not true. For example, most people in the United States do not have a college degree. In our school, students who are the first in their family to attend college can feel alone and different, so it can be useful to explore the statistics surrounding higher education (as well as issues related to the minimum wage, childcare, and poverty; the Pew Research Center and Gallup, for example, both offer data on a wide range of areas). Similarly, many people (probably millions) practice a religion that is unfamiliar to any one of us. Whether students have had past interactions with many people with different faith traditions, they likely will in their future workplaces.

- All of us grew up receiving certain messages about race, gender, religion, abilities, and class. It is helpful for students to reflect on what they learned about these issues in the past. They are not necessarily governed today by those messages and may even disagree with them. But asking students to consider what they saw, read, and heard (at home, on television, on a sports team, etc.) may cause them to explore their beliefs more carefully and help them remember that others grew up with different messages. It opens a door to empathizing with others. ${ }^{3}$

\section{These Issues Matter—No Matter What Your Opinion Is}

If nothing else, many business students are pragmatic and therefore want to learn something that will help them get a job or advance in their career. A good place to start is to emphasize that the companies that they want to work for care about these issues. Especially after the killing of George Floyd, businesses have been outspoken in their concern about minority communities (Dill, 2020). Business executives have told heartbreaking stories about their own experience with racism (Safdar \& Hagey, 2020). Management consulting firm McKinsey \& Company includes on its website articles about how

\footnotetext{
${ }^{3}$ Professor Dawn D. Bennett-Alexander, retired Associate Professor Emeritus at the University of Georgia, has a classroom exercise surrounding this idea of asking students to reflect on the messages they received in media and other sources; see, e.g., Bennett-Alexander, 2018).
}

Journal of the Scholarship of Teaching and Learning, Vol. 21, No. 4, December 2021. josotl.indiana.edu 
the pandemic has disproportionately impacted Asian American communities, and ways for businesses to improve the lives of LGBTQ+ employees (McKinsey, 2021). The National Association of Colleges and Employers (2021) recently found that about one third of responding companies had made "a lot of change" since June 2020 in trying to achieve a diverse workforce through recruiting and hiring, and $58 \%$ had instituted a new or additional department focused on diversity, equity and inclusion. Similarly, LinkedIn reported that most (78\%) of job seekers on its site "expect to find diversity, equity, and inclusion (DEI) information on a company's LinkedIn Page" (Srinivasan, 2021). The ability to discuss these important issues intelligently will help students in their careers-even if their opinions might be different from mine or their classmates'.

Moreover, students will work around people with religious and cultural backgrounds that may be unfamiliar to them. No matter what students think about lightning rod issues, they need to be sensitive to differences at work. Their employers expect it, and those employers expect us to help prepare them. If, for example, a student believes that homosexuality is unacceptable (we have heard this in our class), then there is no point in arguing about whether that is true; that student likely has a strongly held belief based in a faith and family tradition. But it can help to explore what a belief such as that means in a diverse workforce. Discrimination on that basis is illegal, for example, and most students agree that everyone deserves a workplace free of bullying or threats based on their identity.

\section{The Issue of Disabilities Is a Good Place to Start}

Beginning with a topic unlikely to lead to heated disagreement is helpful for building community in the classroom. The more polarizing topics can wait. Differences based on ability tends to be the least polarizing topic, and so this is a good place to start. Indeed, the data indicate that college students may be particularly sympathetic when it comes to disabilities-perhaps especially during the COVID pandemic. Young people aged 18-29 have shown "higher levels of psychological distress than other age groups," as "shutdowns have disrupted job opportunities, college experiences, and the mixing and mingling that marks the transition to adulthood" (Keeter, 2021). And as a group, people aged 18-25 are more likely to have experienced mental illness and may seek an accommodation at work for it (Weber, 2020). ${ }^{4}$

In learning about disabilities, it is helpful to emphasize how late in U.S. history disabled people gained legal rights, and the ways in which those rights are still not fully realized. Aside from the legal basics, it is a chance to explore deeper issues of humanity. Students seemed to most value current events and personal introspection, such as when we asked them to:

- explore whether they have ever had a coach, teacher, or organizational leader with a visible disability;

- watch a film such as the Netflix original "Crip Camp" and Trevor Noah's interview with Judith Heumann;

- discuss Walmart's decision to eliminate the role of "greeter," which was filled by many disabled people, and to replace it with a job that requires the ability to stand and lift heavy objects;

- consider how those with "invisible disabilities" face additional challenges of deciding when and how to disclose them (see, e.g., Solomon, 2020).

\footnotetext{
${ }^{4}$ Weber noted that students receiving an accommodation for difficulties such as attention deficit disorder more than tripled from 2000 to 2016, and that charges filed with the Equal Employment Opportunity Commission for discrimination related to anxiety disorders rose from 65 in 2006 to 371 in 2019).
}

Journal of the Scholarship of Teaching and Learning, Vol. 21, No. 4, December 2021. josotl.indiana.edu 
Watching children crawl up the steps of the U.S. Capitol or stop traffic in New York City, all in a fight for basic access to public spaces, creates empathy in most students. And such empathy lays a helpful foundation for moving onto more divisive issues. It is also helpful to students in their future lives. "Empathy has been cited as making 'young people more productive in work environments that require cooperation’ and in a complex global economy” (Franzese, 198 n. 18, 2017).

\section{Reflective Assignments Allow for More Thoughtful Processing of Provocative Topics}

Affirmative action in employment, and the related consideration of race in college admissions, are widely misunderstood (e.g., when and how race may lawfully be considered) and quickly lead to heated arguments. Instead of tackling them all in a classroom discussion, we can provide students with a quieter space in which to learn. This includes assignments such as the following:

- Before the class discusses a topic, write down and submit to the instructor questions about it. What are your preconceived ideas about it? What would you like to know more about?

- Listen to a podcast or read an article and then record a conversation with a classmate on Zoom in which you discuss the issue.

- Before class, write down points you would like to make, or questions you would like to ask, during a civil debate about these issues in class.

- Write a short reflection about something you learned or something that has challenged your beliefs. ${ }^{5}$

\section{Give Students Some Freedom}

It was helpful to allow students some choice over what they learned and how they showed it. This is not realistic for every assignment; after all, we want our students to watch, listen to, and read some of the same things for shared experiences. But students can learn much more than what we have time in class to discuss. To both deepen their learning and also give them autonomy, assignments with a menu of choices worked well. That menu included articles, podcast, cases, movies, and even John Oliver episodes. These choice assignments allowed students to go deeper into areas that interested them. For example, the entire class read something about redlining, but some students also chose to learn how redlining has caused mostly minority neighborhoods to suffer more extreme effects of climate change (see Plumer et al., 2020). Having a choice appeals to students, and providing students with some autonomy over their learning is a key to increasing intrinsic motivation (see, e.g., McGuire et al., 2015).

A journaling-style exercise worked well to assess student learning about their chosen assignment. This allowed students to provide a regular but informal response to what they read, listened to, or watched that week. Most business school assignments are not like that: informal, without strict assignment parameters or minimum length requirement and without having to worry about (for example) rules of grammar and punctuation. We were slow to warm up to this idea (because of our concern that students should know how to write well). But because a goal of the class is personal growth and thoughtfulness, it makes sense to let them focus on that more than sentence structure.

\footnotetext{
5 "Encouraging student reflexivity" has been described as "a core tenant of racial justice education" (Thurber et al., 2019).

Journal of the Scholarship of Teaching and Learning, Vol. 21, No. 4, December 2021. josotl.indiana.edu
} 


\section{Create an Open Atmosphere}

The following are strategies that help encourage discussion and avoid alienation in class discussions. Scholars have noted that some students may not have thought deeply about some issues and recommend that instructors use "strategic empathy": "resisting the urge to correct misinformation and adopting instead a stance of inquiry into the complex and contradictory motivations of students in order to promote self-reflection and critical thinking" (Thurber et al., 2019). First, let students respond to others' opinions, rather than having us, the instructors, argue with students (see, e.g., Davidson \& Major, 2014). In our experience, letting other students respond and point out possible flaws in arguments is more effective than the instructor doing so. Occasionally we correct misstatements of fact or point out facts that a student may be ignoring but usually other students are effective at this. Another important caveat would be if a student is disrespectful, which would require some interference and/or guidance, including possibly a conversation with that student outside of class. Fortunately, we have found that most of our students are able to have respectful conversations even in the face of disagreements about controversial topics. This makes sense, considering the wellresearched value of students learning from each other.

Students appreciate open discussion. For example, two students in one class often had conflicting viewpoints; however, both recognized the other student as having contributed to their learning. One wrote:

In class I often played devil's advocate and shared differing opinions, but I really enjoyed going back and forth. ... I learn very well from discussion-based classes, especially with people who do not agree. I think everyone did a great job of opening up to the idea of being wrong, and I certainly was several times which enhanced the experience for me greatly.

Second, openly acknowledging how difficult and uncomfortable these topics can be to discuss - and that it is acceptable both to be uncomfortable and to have different opinionsencourages a more open and honest discussion (see, e.g., Alexander-Floyd, 2008, who noted the importance of explaining that topics such as race and racism might cause discomfort; see also Kawashima-Ginsberg \& Junco, 2018, who discussed the importance of "embracing disagreements" to promote productive discussions). Using what others have said about both the importance and discomfort of these discussions is one way to acknowledge this. For example, Brené Brown's (2018) book Dare to Lead has a passage that effectively explains that even though talking about race can be uncomfortable, it is also important and that silence is not an acceptable option. Additionally, explicitly thanking students for speaking up can help encourage discussion and civic discourse. This lets students know that their opinions are welcome (even if they are challenged).

Third, asking students to consider what might change their minds can help them see things differently while also respecting their position. This can include a fill-in-the-blank prompt such as, "I (agree/disagree) with using affirmative action because , but if were true, I might change my mind." We then discuss how students filled in these blanks, which can result in students better understanding where and why they both disagree and agree. Finding points of agreement can lead to an open mind about others' positions and less polarization.

Finally, debates (even informal ones) can engage students without alienating them, particularly if they are randomly assigned to a side. Giving students 15 minutes to prepare talking points and then debate allows them to see a different point of view, especially if they have to argue in support of a side with which they disagree. Because finding common ground is an important part of both debate and civil discourse, working to understand other viewpoints can help students find common ground with those who have different opinions and hopefully lead to more empathy and less polarization.

Journal of the Scholarship of Teaching and Learning, Vol. 21, No. 4, December 2021. josotl.indiana.edu 


\section{Using Our Experience to Look Ahead}

We are encouraged that business and universities, including our own, are having important conversations about race, gender, and other dimensions of difference. Although diversity and inclusion topics can be difficult or uncomfortable in many settings, including the classroom, we did receive positive student feedback. Of course, along with positive feedback, some comments on course evaluations complained about the instructor being "too liberal" or "blaming white men for everything." And although that can be discouraging and these disgruntled students are part of the audience we are trying to reach, we must also realize that they are not our only audience. Indeed, we also have a large constituency that is open to learning or that even have experienced discrimination of some sort firsthand. Therefore, we need to also give those students room to learn and think, as well as to discuss their own lived experiences.

Given our experiences to date, we will continue to rethink how to teach these critical issues. We want the same things from ourselves that we want from our students: more listening, more sharing, more community building, more empathy, more questioning. We will continue to strive to model these behaviors while also creating an atmosphere where all are comfortable respectfully discussing these topics and being open to others' viewpoints. We hope our students leave our classes knowing that they have more to learn and understanding the importance of doing so. It is challenging to teach these issues right now; but when would it not have been?

\section{References}

Alexander-Floyd, N. (2008). Critical race pedagogy: Teaching about race and racism through legal learning strategies. PS: Political Science \& Politics, 41(01), 183-188. https://doi.org/10.1017/s1049096508080281

Bail, C., Argyle, L. P., Brown, T. W., Bumpus, J. P., Chen, H., Hunzaker, M. B. F., Lee, J., Mann, M., Merhout, F., \& Volfovsky, A. (2018). Exposure to opposing views on social media can increase political polarization. Proceedings of the National Academy of Sciences of the United States of America, 115(37), 9216-9221. https://doi.org/10.1073/pnas.1804840115

Bennett-Alexander, D. (2018). Why and how to incorporate diversity \& inclusion into the classroom [Online workshop]. McGraw Hill. https://www.mheducation.com/highered/insights-ideas/whyand-how-to-incorporate-diversity-with-dawn-bennett-alexander.html

Bhutta, N., Chang, A., Dettling, L., \& Hsu, J. (2020). Disparities in wealth by race and ethnicity in the 2019 Survey of Consumer Finances. Federal Reserve. Retrieved September 17, 2021, from https://www.federalreserve.gov/econres/notes/feds-notes/disparities-in-wealth-by-raceand-ethnicity-in-the-2019-survey-of-consumer-finances-20200928.htm

Bloomington Faculty Council. (2021). Indiana University. https://bfc.indiana.edu/diversitylearning-outcomes/learning-outcomes.html

Brown, B. (2018). Dare to lead: Brave work. Tough conversations. Whole hearts. Vermillion.

Churchill, L. (2020). Ethics for everyone. Oxford University Press.

Coates, T. (2014, June). The case for reparations. The Atlantic. https://www.theatlantic.com/magazine/archive/2014/06/the-case-forreparations $/ 361631 /$

Davidson, N., \& Major, C. H. (2014). Boundary crossings: Cooperative learning, collaborative learning, and problem-based learning. Journal on Excellence in College Teaching, 25(3\&4), 7-55.

Journal of the Scholarship of Teaching and Learning, Vol. 21, No. 4, December 2021. josotl.indiana.edu 
Dill, K. (2020, June 5). A conclave of America's top CEOs talks race and making change. Wall Street Journal. https://www.wsj.com/articles/a-conclave-of-americas-top-ceos-talks-race-andmaking-change- $11591349402 ? \mathrm{mod}=$ article relatedinline

Dimock, M., \& Gramlich, J. (2021, January 29). How America changed during Donald Trump's presidency. Pew Research Center. https://www.pewresearch.org/2021/01/29/how-america-changedduring-donald-trumps-presidency/

Dobbin, F., \& Kelev, A. (2016, July-August). Why diversity programs fail. Harvard Business Review. https://hbr.org/2016/07/why-diversity-programs-fail

Eberhardt, J. (2020). Biased: Uncovering the hidden prejudice that shapes what we see, think, and do. Penguin Books.

Finkel, E. J., Bail, C. A., Cikara, M., Ditto, P. H., Iyengar, S., Klar, S., Mason, L., McGrath, M. C., Nyhan, B., Rand, D. G., Skitka, L. J., Tucker, J. A., van Bavel, J. J., Wang, C. S., \& Druckman, J. N. (2020). Political sectarianism in America. Science, 370(6516), 533-536. https://doi.org/10.1126/science.abe1715

Franzese, P. A. (2017, April 21). The power of empathy in the classroom [Seton Hall public law research paper]. Seton Hall Law Review, 47(693). https://ssrn.com/abstract=2956433

Gilberstadt, H., Hartig, H., Jones, B., Dunn, A., Doherty, C., Kiley, J., Daniller, A., van Green, T., \& Gomez, V. (2020, September 10). Voters' attitudes about race and gender are even more divided than in 2016. Pew Research Center-U.S. Politics \& Policy. https://www.pewresearch.org/politics/2020/09/10/voters-attitudes-about-race-andgender-are-even-more-divided-than-in-2016/

Grobman, M. (2019, June 26). Why diversity training fails to achieve desired results and how to fix this. Forbes. https://www.forbes.com/sites/miriamgrobman/2019/06/26/why-diversitytraining-fails-to-achieve-desired-results-and-how-to-fix-this $/$ ?sh $=2846 \mathrm{bf} 797852$

Hansen, M. D. Q. (2020, April 27). Latest NAEP results show American students continue to underperform on civics. Brookings. https://www.brookings.edu/blog/brown-centerchalkboard/2020/04/27/latest-naep-results-show-american-students-continue-tounderperform-on-civics/

Harvard University Derek Bok Center for Teaching and Learning. (n.d.). Key moves. Retrieved September 28, 2021, from https://bokcenter.harvard.edu/inclusive-moves\#navigatingdifficult-moments

Indiana University Center for Innovative Teaching and Learning. (n.d.). Managing difficult classroom discussions. Retrieved September 28, 2021, from https://citl.indiana.edu/teachingresources/diversity-inclusion/managing-difficult-classroom-discussions/index.html

Kawashima-Ginsberg, K., \& Junco, R. (2018). Teaching controversial issues in a time of polarization. Social Education, 82(6), 323-329.

Keeter, S. (2021, March 16). Many Americans continue to experience mental bealth difficulties as pandemic enters second year. Pew Research Center. https://www.pewresearch.org/facttank/2021/03/16/many-americans-continue-to-experience-mental-health-difficulties-aspandemic-enters-second-year/

Kernahan, C. (2019). Teaching about race and racism in the college classroom: Notes from a White professor. West Virginia University Press.

McAvoy, P., \& Hess, D. (2013). Classroom deliberation in an era of political polarization. Curriculum Inquiry, 43(1), 14-47. https://doi.org/10.1111/curi.12000

McGuire, S. Y., McGuire, S., \& Angelo, T. (2015). Teach students how to learn: Strategies you can incorporate into any course to improve student metacognition, study skills, and motivation. Stylus Publishing.

McKinsey. (2021). Diversity and inclusion. Retrieved September 28, 2021, from https://www.mckinsey.com/featured-insights/diversity-and-inclusion

Journal of the Scholarship of Teaching and Learning, Vol. 21, No. 4, December 2021. josotl.indiana.edu 
National Association of Colleges and Employers. (2021). NACE September 2021 quick poll: Racial injustice follow up. Retrieved September 28, 2021, from https://www.naceweb.org/diversityequity-and-inclusion/trends-and-predictions/nace-september-2021-quick-poll-racialinjustice-follow-up/

Pace, D. (2003). Controlled fission: Teaching supercharged subjects. College Teaching, 51(2), 42-45. https://doi.org/10.1080/87567550309596410

Pew Research Center. (2021, August 12). Deep divisions in Americans' views of nation's racial history-And how to address it. https://www.pewresearch.org/politics/2021/08/12/deep-divisions-inamericans-views-of-nations-racial-history-and-how-to-address-it/

Plumer, B. (Author), Popovich, N. (Author), \& Palmer, B. (Photogapher). (2020, August 24). How decades of racist housing policy left neighborhoods sweltering. New York Times. https://www.nytimes.com/interactive/2020/08/24/climate/racism-redlining-cities- globalwarming.html

Quillian, L., Pager, D., Hexel, O., \& Midtbøen, A. H. (2017). Meta-analysis of field experiments shows no change in racial discrimination in hiring over time. Proceedings of the National Academy of Sciences of the United States of America, 114(41), 10870-10875. https://www.pnas.org/content/114/41/10870

Rothstein, R. (2017). The color of law: A forgotten history of how our government segregated America. Liveright. Safdar, K., \& Hagey, K. (2020, June 26). Black executives are sharing their experiences of racism, many for the first time. Wall Street Journal. https://www.wsj.com/articles/black-executivesare-sharing-their-experiences-of-racism-many-for-the-first-time- 11593182200

Solomon, A. (2020, July 10). What happens when you're disabled but nobody can tell. New York Times. https://www.nytimes.com/2020/07/10/style/invisible-disabilities.html

Srinivasan, H. (2021, August 10). Helping our customers source and build more diverse talent pools. LinkedIn. https://www.linkedin.com/business/talent/blog/product-tips/source-and-build-morediverse-talent-pools

Thurber, A., Harbin, M. B., \& Bandy, J. (2019). Teaching race: Pedagogy and practice. Vanderbilt University Center for Teaching. Retrieved September 10, 2021, from https://cft.vanderbilt.edu/teaching-race/

University of Michigan Center for Research on Learning \& Teaching. (n.d.). Guidelines for discussing difficult or high-stakes topics. Retrieved September 28, 2021, from https://crlt.umich.edu/publinks/generalguidelines

Weber, L. (2020, February 12). Young workers seek mental health accommodations, employers try to keep up. Wall Street Journal. https://www.wsj.com/articles/managing-mental-health-atwork-is-a-juggle-of-rights-and-realities-11581523201

Wood, T., \& Porter, E. (2019). The elusive backfire effect: Mass attitudes' steadfast factual adherence. Political Behavior, 41, 135-163. https://doi.org/10.1007/s11109-018-9443-y 